\title{
УКРАЇНСЬКО-ПОЛЬСЬКІ ТА ПОЛЬСЬКО-УКРАЇНСЬКІ СЛОВНИКИ МЕДИЧНОЇ ТЕРМІНОЛОГЇ̈: СУЧАСНИЙ СТАН ТА ПРОБЛЕМИ
}

у статті розглянуто й проаналізовано сучасні українсько-польські та польсько-українські словники медичної термінології. Здійснено спробу виокремити переваги та недоліки цих тексикограбічних праць. Порушено проблему доступності фахових термінологічних словників на книжковому ринку або взагалі їх відсутність. Наголошено на необхідності укладання двомовних украӥнсько-польських та польсько-украӥнських медччних словників із тлумаченням термінів.

Ключові слова: лексикографія, двомовний словник, медична термінологія, українські та польські медичні терміни.

Kovalevska O. O. Ukrainian-Polish and Polish-Ukrainian Dictionaries of Medical Terminology: Current Status and Problems. The last decade is characterised by the dynamic development of Ukrainian-Polish relationships in different areas of life: education, economics, trade, medicine, culture, etc. This phenomenon has a direct impact on the increasing number of language contacts, which requires from the interlocutors not only the understanding, but also the basic knowledge of Polish and Ukrainian languages. A demand for the services of specialised translators is rising, especially of those with the expertise in a particular field. However, translators complain about the limited number of, obsolescence or even a complete lack of Ukrainian-Polish and Polish-Ukrainian terminological dictionaries. Translations are often done via Russian, English and Latin, in which the required lexicographic works are available. Considering this, the author of the present article resolved to analyse the bilingual dictionaries of medical terminology due to their limited number, which fails to meet the requirements of the users.

The aim of the article is to describe the Ukrainian-Polish and Polish-Ukrainian dictionaries of medical terminology by identifying their advantages and disadvantages. Such analyses will help to illustrate the current state and highlight the problems of this type of works.

The analysis of Ukrainian-Polish and Polish-Ukrainian dictionaries of medical terminology allows tracing certain advancements in compiling such lexicographic works. However, it also involves pointing to some areas that have been overlooked or neglected, particularly the choice of corresponding terms, and the criteria for selecting the entries. The dictionaries are incomplete in terms of their volume and, therefore, do not meet the requirements of the modern society. Another problem is the limited access to such type of works, as they were published in limited editions 10-20 years ago. 
Currently there is a growing need to compile a Ukrainian-Polish and Polish-Ukrainian medical dictionary that would not only include the equivalents of terms, but also their definitions. This would help fill the gap that exists in modern lexicography.

Key words: lexicography, bilingual dictionary, medical terminology, Ukrainian and Polish medical terms.

\section{Вступ}

Останнє десятиліття демонструє динамічний розвиток українсько-польських відносин у різних сферах життя: освіті, економіці, торгівлі, медицині, культурі й ін. Це безпосередньо впливає на збільшення мовних контактів, що вимагає від співрозмовників не лише розуміння, а й володіння на комунікативному рівні польською та українською мовами. Зростає попит на послуги фахових перекладачів, зокрема таких, що спеціалізуються на конкретній галузі, наприклад, правознавстві, будівництві чи логістиці. Однак перекладачі нарікають на незначну кількість, застарілість або взагалі відсутність українсько-польських та польсько-українських термінологічних словників. Часто переклади виконуються за посередництвом російської, англійської чи латинської мов, де такі лексикографічні праці існують. Саме це спонукало автора до аналізу перекладних словників медичної термінології, оскільки їх кількість дуже обмежена та не задовольняє потреб користувачів.

Українсько-польська лексикографія була предметом наукових розвідок таких мовознавців, як Й. Дзендзелівський, Т. Космеда, I. Кононенко, Н. Коциба, М. Турска, К. Воян, І. Сус, М. Лукасік та ін. Медичну термінологію цих мов у зіставному аспекті досліджували О. Борис, Р.-Ю. Перхач, Л. Париляк та ін. Однак на сьогодні відсутні праці, присвячені аналізу саме двомовних медичних словників.

Метою статті $є$ опис українсько-польських і польсько-українських словників медичної термінології, зокрема виокремлення їхніх переваг і недоліків, що дасть змогу окреслити сучасний стан та проблеми праць зазначеного типу.

\section{Методи та методики дослідження}

Специфіка аналізованого матеріалу та мета наукової розвідки зумовила використання таких методів, як описовий (для систематизації зібраного лексикографічного матеріалу та аналізу структури досліджуваних словників), зіставний (для порівняння медичних термінів 
у польській та українській мовах), а також метод аналізу словникових дефініцій (для визначення семантики реєстрових одиниць аналізованих лексикографічних праць).

\section{Результати та дискусії}

У 1999 році в польському видавництві «Zapol» вийшов друком «Mały słownik terminologii medycznej: język polski, język łaciński, język ukraiński» (Щецин, 1999), укладений Г. Шуміловичем, професором Поморського медичного університету в Щецині. Це перша в історії сучасної польсько-української лексикографії праця, присвячена медичній термінології. Робота над словником тривала протягом 19921998 рр. Налічує він понад 6000 основних термінів з галузі медицини й споріднених наук: хімії, біології та техніки.

Традиційно реєстрові одиниці у лексикографічній праці розташовані за алфавітом. Словникова стаття має такий вигляд: польський медичний термін $\rightarrow$ його відповідник у латинській мові $\rightarrow$ український еквівалент, напр.: łydka - sura, ae, f. - литка (Szumiłowicz, 1999: 117). Варто зауважити, що укладач дотримується загальноприйнятих правил словникового запису латинських термінів, а саме: після іменника в називному відмінку вказано закінчення родового відмінка та скорочено рід іменника (напр. biopsja - biopsia, ae, f. - біоnciя (Szumiłowicz, 1999: 22)), після прикметника, вжитого в чоловічому роді, подано закінчення жіночого та середнього родів (напр. żeński - femininus, a, um - жіночий (Szumiłowicz, 1999: 277)). Хоча в словниковій статті першим подано польський термін, проте автор праці передусім орієнтується на латинську медичну термінологію. Це засвідчує, зокрема, вибір відповідників в українській мові: першим завжди запропоновано український термін латинського походження, якщо такий існує, потім - українські (питомі) еквіваленти, напр.: bezsenność asomnia, ae, f. - асомнія, безсоння, безсонність (Szumiłowicz, 1999: 21). Польські реєстрові одиниці подано без синонімів, тому іноді натрапляємо на статті, де замість питомого терміна запропоновано його латинський відповідник, напр.: апuria - anuria, ae, f. - анурія, анурез, безсеччя (Szumiłowicz, 1999: 14). У цьому разі доречно вжити термін bezmocz, який значно частіше використовують у польському медичному дискурсі. Серед українських синонімів еквівалентного типу натрапляємо на лексеми, які застаріли або ж вкрай рідко вживаються в фаховій медичній літературі, напр.: blizna - cicatrix, icis, f. - щрам, 
рубець, близна (Szumiłowicz, 1999: 23), łechtaczka - clitoris, idis, f. - клiтор, скоботень (Szumiłowicz, 1999: 115), łożysko - placenta, ae, f. - плаиента, ложисько, послід, иистило (Szumiłowicz, 1999: 116).

У вступному слові Г. Шумілович наголошує, що «польська медична термінологія, становлена протягом багатьох років (подібно й латинська) не спричинила авторові жодних проблем - проте в українських термінах виступало чимало розходжень» (Szumiłowicz, 1999: 5). Не дивно, що в автора виникали труднощі, адже укладання словника припало на антирусифікаційний період розвитку української медичної термінології, що розпочався в 90-х рр. ХХ ст. (Жовтобрюх, 2012: 25). У той час також тривали роботи над усталенням норм українського правопису. 31991 р. до сьогодні в Україні видано понад 100 словників з різних медичних спеціальностей, проте «проблема остаточного внормування та уніфікації медичної термінології ще не вирішена» (Васильовська 2017: 117).

Незважаючи на те, що аналізованиий словник було видано 20 років тому, він не втратив своєї цінності та дотепер залишається найбільшим за обсягом реєстру польсько-української медичної термінології. 3 огляду на малий тираж, із працею можна ознайомитися лише у кількох бібліотеках Польщі.

Завдяки співпраці Вінницького національного медичного університету ім. М. І. Пирогова та Краківської окружної лікарської палати у 2003 р. було видано «Малий медичний словник українсько-польський і польсько-український» (Краків, 2003), укладений А. Костюченком і В. Костюченком. Словник містить близько 5000 медичних термінів, що їх активно вживають у лікарській практиці. У вступному слові автори наголошують, що ця лексикографічна праця «буде гарним посібником для лікарів та студентів медичних закладів» (Костюченко, 2003: 5).

Принцип розташування одиниць у словнику - абетковий. Реєстрові слова подано в початковій формі без зазначення граматичних форм, умовних позначень чи дефініцій, напр.: cmpaвохід - przełyk (Костюченко, 2003: 60), gruczol - залоза (Костюченко, 2003: 93). В окремих статтях після основного терміна пропонуються синоніми еквівалентного типу, що паралельно функціюють у медичному дискурсі, як-от: токсикоз - toksykoza; zatrucie (Костюченко, 2003: 63), dna, skaza mосzапоwa - подагра; сечокислий діатез (Костюченко, 2003: 85). Застарілих, діалектних та маловживаних назв на позначення понять 
укладачі не наводять, а зосереджують увагу, передусім, на активній лексиці, що заслуговує на схвалення.

Проте лексикографічна праця має ряд недоліків, які не можемо залишити без уваги. Укажемо, зокрема, на факт не завжди правильного добору еквівалентів, напр.: сколіоз - skrzywienie kregosłupa boczne (Костюченко, 2003: 59). Це невдалий відповідник, оскільки в польській медичній практиці насамперед використовують термін skolioza. Словосполучення boczne skrzywienie kręostupa не є терміном і вживається в розмовному стилі. Хоча така назва побутує, вона не зовсім відповідає поняттю, адже сколіоз - це не тільки бічна кривизна, а й тривимірна. Окрім того, у деяких словникових статтях терміни з різних галузей подано як синонімічні еквіваленти, що є неприпустимим, напр.: $\dot{z} о-$ łądź - жолудь; голівка (Костюченко, 2003: 158). У польській мові лексема żoładź використовується одночасно у двох терміносистемах для вираження різних понять: у ботаніці - плід дуба (український відповідник - жолудь), а в анатомії - конусоподібне потовщення чоловічого статевого органу (український відповідник - голівка статевого члена). Подібні недогляди можуть вплинути на невластиве засвоєння термінів користувачами, а також на якість виконання перекладів.

У вступному слові укладачі декларують, що словник охоплює основні медичні терміни, проте в ньому широко представлена загальновживана лексика, напр.: печериия - pieczarka (Костюченко, 2003: 49), щцавель - szczaw (Костюченко, 2003: 72), herbata - чай (Костюченко, 2003: 94), krewny - родич (Костюченко, 2003: 101) та ін. Також зустрічаємо терміни з інших галузей наук, а саме: хімії (натріŭ - sód; $\mathrm{Na}$ (Костюченко, 2003: 43)), зоології (тарган - karaluch (Костюченко, 2003: 61)), географії (biegun - полюс (Костюченко, 2003: 81)), сільського господарства (hodowanie - вирощування, культивування (Костюченко, 2003: 95)). Не зрозуміло, чому ці одиниці ввійшли до реєстру і який був принцип добору словникових статей. Згадані неточності та зауваження слід врахувати під час підготовки наступних видань. Зауважимо, що доступний спосіб викладу матеріалу в словнику розширює коло користувачів, які прагнуть збагатити свої мовні компетенції медичною термінологією.

Безумовно, значним внеском у розвиток польсько-української лексикографії, а саме термінологічних праць, вважаємо «Słownik terminów biologicznych ukraińsko-polski i polsko-ukraiński» (Варшава 2006), укладений В. Козубелем. Словник охоплює 5000 основних 
термінів з різних галузей біологічних знань, зокрема: медицини, анатомії, ботаніки, генетики, геології, екології, а також математики, фізики та хімії, на що вказують умовні позначки. Праця адресована учням польських шкіл з українською мовою навчання, проте стане в пригоді перекладачам та кожному, хто прагне вдосконалювати свої мовні компетенції.

Статті в словнику розміщено в алфавітному порядку, що дає змогу швидко знайти потрібний термін. Варто зауважити, що українські слова записано з наголосами: це повинно допомогти носіям польської мови в засвоєнні правильної вимови. Якщо термін у польській або українській мові має синоніми, то їх подано після основної назви, напр.: nульс - tętno, puls (Kozubel, 2006: 34), цинга мед. - szkorbut, gnilec (Kozubel, 2006: 42). Можемо помітити, що не завжди подається повний синонімічний ряд. До прикладу, в статті cewka moczowa - сечівник, сечостатевий канал (Kozubel, 2006: 50) не згадано синоніма уретра, що має латинське походження і часто використовується в українському медичному дискурсі. Цільовою аудиторією словника передусім є учні загальноосвітніх шкіл, можливо, тому укладач обирав лише основні синоніми, щоб полегшити засвоєння навчального матеріалу. Багато медичних термінів залишилися без умовних позначень, що вказують на галузь, напр.: błona bębnowa - барабанна перетинка, błona śluzowa - слизова оболонка (Kozubel, 2006: 49). Поодиноко трапляються терміни, де під впливом польської мови порушений порядок слів, напр.: імпульс нервовий - impuls nerwowy (Kozubel, 2006: 19) (правильно - нервовий імпульс). Ці дрібні недогляди варто усунути в наступних виданнях словника.

Не можна залишити поза увагою ще одну лексикографічну працю В. Козубеля «Słownik terminów chemicznych ukraińsko-polski i polsko-ukraiński» (2007). Хоча словник передусім адресовано учнівській молоді, проте він стане в пригоді працівникам медичних лабораторій та фармацевтам. Видання налічує близько 2000 основних термінів з різних галузей хімії, а також наук, пов'язаних із цією дисципліною (біологія, екологія, математика, фізика та ін.). Принцип опису словникових статей такий самий, як у попередній праці автора, пор.: ва́куум фіз. - рróżnia (Kozubel, 2007: 10), трикарбо́вані кисло́ти - kwasy trójkarboksylowe (Kozubel, 2007: 30), епzym biol. - фермент, ензим (Kozubel, 2007: 42). У словнику також представлено терміни, що їх використовують у медицині, проте ці одиниці не мають відповідної 
умовної позначки, напр.: до́за - dawka (Kozubel, 2007: 13), alkaloid алкало́ïd (Kozubel, 2007: 37), eter - eøíp (Kozubel, 2007: 42). Як декларує автор праці в передмові, польські й українські назви хімічних елементів і сполук подано з дотриманням правил Міжнародної спілки чистої та прикладної хімії (ІЮПАК), Номенклатурної комісії Польського хімічного товариства, стандартів ДСТУ 2439-94 «Елементи хімічні та речовини прості. Терміни та визначення основних понять. Умовні позначення» та Національної комісії України з хімічної термінології й номенклатури. Це, без сумніву, демонструє професійний підхід до вибору реєстрових одиниць словника.

Заслуговує на увагу також «Słownik tematyczny polsko-ukraiński» (Варшава, 2010), укладений I. Кононенко, І. Митнік, Е. Васяк. Лексикографічна праця адресована широкому колу користувачів: студентам, перекладачам, підприємцям, фахівцям з різних сфер, зокрема лікарям. Словник налічує близько 45000 слів та словосполучень, що входять до 30 тематичних блоків, один з яких присвячений медичній службі та медичній допомозі (Kononenko, 2010: 117-146). У цьому блоці виокремлено такі семантичні групи: «Лікувальні заклади», «Медичний персонал, спеціальності», «Медична допомога», «Хвороби», «Медичне оснащення», «Ліки та перев'язочні матеріали». Терміни 3 анатомії, а саме назви частин тіла та внутрішніх органів, елементи будови ока, зуба й скелету, знайдемо у групі «Людське тіло та організм, анатомія» (Kononenko, 2010: 23-28), що входить до тематичного блоку «Людина».

Українські слова мають зазначений наголос, що безперечно знадобиться польськомовним користувачам, напр.: nerwica - невро́з, obrzęk - на́бряк (Kononenko, 2010: 134). Зауважимо, що в кожній семантичній групі окремо подано іменники, прикметники (дієприкметники) та дієслова в алфавітному порядку, а також словосполучення з цими частинами мови, пор.: dbać o zdrowie - niклува́тися про здоро́в'я, oddać krew - зда́mи кров (Kononenko, 2010: 127). Подекуди укладачі подають через кому синоніми, напр.: cewnikowanie, katetetyzacja - зондува́ння, катетериза́ція (Kononenko, 2010: 124), okulista, oftalmolog - окуліст, офтальмолог (Kononenko, 2010: 123). Проте прослідковуємо певну непослідовність в оформленні матеріалу, зокрема польський термін kręgarstwo - хіропра́ктика, мануа́льна терапі́ (Kononenko, 2010: 121) викладено окремо, а не додано до синонімів chiropraktyka, terapia manualna - хіропра́ктика, мануа́льна терапі́ 
(Kononenko, 2010: 121). Наприкінці розділів розміщено сталі словосполучення, фразеологізми та речення, що демонструють вживання деяких лексем у мовленнєвих ситуаціях, як-от: Wypadła mi plomba. У ме́не ви́пала пло́мба. Podejrzewam zapalenie dziąseł - Я підо́зрюю, що y ме́не запа́лення я́сен (Kononenko, 2010: 141). Це розширює коло користувачів і дає змогу використовувати видання для навчальних потреб. Хоча словник не належить до термінологічних праць, проте він налічує близько 1500 медичних термінів і словосполучень. Перевагою видання $є$ також його доступність у книгарнях та бібліотеках.

\section{Висновки}

Отже, аналіз українсько-польських та польсько-українських словників медичної термінології дає змогу говорити про певні напрацювання в укладанні лексикографічних праць такого типу, проте помічаємо значні недогляди, передусім у виборі термінів-відповідників, а також у принципах добору реєстрових одиниць. За обсягом матеріалу це неповні словники, що не задовольняють сучасних суспільних потреб. Однією з проблем є також обмежений доступ до цих праць, адже вони були видані 10-20 років тому невеликим тиражем. Медицина - це галузь, яка динамічно розвивається, тому щороку з'являється близько тисячі нових термінів. Потреба у фахових медичних словниках, зокрема перекладних, зростає. Погоджуємося з твердженням польської дослідниці Б. Остроменцької-Фрончак, що «для користувача, який хоче вивчити іноземну мову та досягти комунікативних навичок за короткий термін, важливішим є когнітивний еквівалент, тоді як опис перекладних еквівалентів збільшує значення словника при перекладі та є безцінним для перекладача» (Ostromęcka-Frączak, 1998: 392). Сьогодні постає необхідність в укладанні тлумачного українсько-польського та польсько-українського медичного словника, що містив би, окрім еквівалентів, також дефініції термінів. Це допомогло б заповнити прогалину, що існує в сучасній лексикографіï.

\section{ЛІТЕРАТУРА}

1. Васильовська I. Сучасний стан та проблеми української медичної термінологіі. Теорія і практика викладання української мови як іноземної. 2017. Вип. 13. C. 116-121. http://dx.doi.org/10.30970/ufl.2018.13.1987. 2. Жовтобрюх Н. Становлення української медичної термінології. Сучасні проблеми мовознавства та літературознавства. 2012. Вип. 17. С. 25-29. 3. Костюченко А. В., Костюченко В. А. Малий медичний словник українсько-польський і польсько-український. Краків: Secesja, 
2003. 158 c. 4 . Kononenko I., Mytnik I., Wasiak E. Słownik tematyczny polsko-ukraiński. Warszawa: Wydawnictwo Naukowe PWN SA, 2010. 550 s. 5. Kozubel W. Słownik terminów biologicznych ukraińsko-polski i polsko-ukraiński. Warszawa: Wydawnictwo Szkolne i Pedagogiczne, 2006. 87 s. 6. Kozubel W. Słownik terminów chemicznych ukraińsko-polski i polsko-ukraiński. Warszawa: Wydawnictwo Szkolne i Pedagogiczne, 2007. 72 s. 7. Ostromęcka-Frączak B. Słownik dwujęzyczny i jego rola w nauczaniu języka polskiego jako obcego. Acta Universitatis Lodziensis. Kształcenie polonistyczne cudzoziemców. 1998. T. 10. S. 389-393. 8. Szumiłowicz G. Mały słownik terminologii medycznej: język polski, język łaciński, język ukraiński. Szczecin: Zapol, 1999. 279 s.

\section{REFERENCES}

1. Vasylovska, I. (2017). Suchasnyi stan ta problemy ukrainskoi medychnoi terminolohii [Current status and problems of Ukrainian medical terminology]. Teoriia $i$ praktyka vykladannia ukrainskoi movy yak inozemnoi - Theory and practice of teaching Ukrainian as a foreign language, 13, 116-121 [in Ukrainian]. 2. Zhovtobriukh, N. (2012). Stanovlennia ukrainskoi medychnoi terminolohii [Formation of Ukrainian medical terminology]. Suchasni problemy movoznavstva ta literaturoznavstva - Modern problems of linguistics and literary studies, 17, 25-29 [in Ukrainian]. 3. Kostiuchenko, A. V. \& Kostiuchenko V. A. (2003). Malyi medychnyi slovnyk ukrainsko-polskyi i polsko-ukrainskyi [Small medical ictidonary Ukrainian-Polish and Polish-Ukrainian]. Krakiv [in Ukrainian]. 4. Kononenko, I., Mytnik, I. \& Wasiak, E. (2010). Słownik tematyczny polsko-ukrainski [Polish-Ukrainian thematic dictionary]. Warszawa: Wydawnictwo Naukowe PWN SA [in Polish]. 5. Kozubel, W. (2006). Słownik terminów biologicznych ukrainsko-polski i polsko -ukraiński [Dictionary of biological terms Ukrainian-Polish and Polish-Ukrainian]. Warszawa: Wydawnictwo Szkolne i Pedagogiczne [in Polish]. 6. Kozubel, W. (2007). Słownik terminów chemicznych ukraińsko-polski i polsko-ukraiński [Dictionary of Ukrainian-Polish and Polish-Ukrainian chemical terms]. Warszawa: Wydawnictwo Szkolne i Pedagogiczne [in Polish]. 7. Ostromęcka-Frączak, B. (1998). Słownik dwujęzyczny i jego rola w nauczaniu języka polskiego jako obcego [Bilingual dictionary and its role in teaching Polish as a foreign language]. Acta Universitatis Lodziensis. Kształcenie polonistyczne cudzoziemców Acta Universitatis Lodziensis. Polish language education for foreigners, 10, 389-393. [in Polish]. 8. Szumiłowicz, G. (1999). Mały słownik terminologii medycznej: język polski, język łaciński, język ukraiński [A small dictionary of medical terminology: Polish, Latin, Ukrainian]. Szczecin: Zapol [in Polish].

Ковалевська Олена Олегівна - кандидат філологічних наук, ад’юнкт кафедри україністики, Університет імені Адамі Міцкевича в Познані. Ал. Неподлеглості 4, м. Познань, 61-874, Польща.

Tel. +48518094025

mail: olena.kowalewska@amu.edu.pl

https://orcid.org/0000-0003-1241-449X

Kowalewska Olena Olehivna - PhD in Philology, Assistant Professor, Department of Ukrainian Studies, Adam Mickiewicz University, al. Niepodległości 4, Poznań, 61-874, Poland. 